In I. Pruin, F. Dünkel and A. Storgaard (eds.) (forthcoming) Prisoner Resettlement in Europe, London: Routledge.

\title{
Women and resettlement in Europe
}

\section{Gill McIvor}

\begin{abstract}
The majority of people who are imprisoned are men which means that the resettlement needs of women may go unrecognised. Because their circumstances prior to imprisonment and the impact of imprisonment on them are different for women, the resettlement needs of women need to be considered separately from those of men. This chapter considers how imprisonment impacts adversely upon different aspects of women's lives including their relationships, accommodation and health and discusses the implications for effective resettlement practices and desistance from crime. It is argued that because of women's marginalisation, resettlement practices need to be underpinned by policies that address wider forms of economic and social disadvantage.
\end{abstract}

\section{Keywords}

Women; imprisonment; resettlement; desistance; marginalisation

\section{Introduction}

In many European countries, the numbers of women imprisoned have increased in recent years reflecting a trend that has been evidenced more widely in other western jurisdictions. Levels of re-offending, while typically lower among women than men possibly because women tend to present lower levels of 'risk'(Blanchette and Brown 2006), are often high following imprisonment, not least because female prisoners have a complex range of problems and needs which may be exacerbated by a period in prison. Despite increasing policy attention in some jurisdictions to prisoner resettlement as a means of reducing levels of re-offending and imprisonment, women's experiences prior to and following release from prison have received more limited empirical and policy attention. Imprisoned women are often serving short prison sentences or are being held on remand and therefore do not have access to effective pre- and post-release support with the result that many women leaving prison will not feel adequately prepared for or supported on release. Drawing on existing research, this chapter will explore the particular challenges faced by women on their release from prison and consider how formerly imprisoned women may be disproportionately disadvantaged by broader economic and social constraints that increase their marginalisation and limit their access to the structural determinants of social justice.

\section{Imprisoned women}

\section{Characteristics, backgrounds and pathways into crime}


Women in the criminal justice system generally and imprisoned women in particular tend to have backgrounds of characterized by severe poverty, disadvantage and abuse. Women's pre-imprisonment histories are often associated with drug and alcohol problems, physical and mental health problems, physical, sexual and emotional victimisation and resulting trauma, low educational attainment, unemployment and, where available, reliance on income from state benefits (Loucks 2004; Dünkel, Kestermann and Zolondek 2005; Gelsthorpe and Sharpe 2007; Baldry 2011; Kerr 2014; Pruin 2016).

A comparative study of imprisoned women in several European countries found that, where the data were available, most female prisoners had a very low educational level, with women from marginalised ethnic groups - such as Roma women - having the lowest levels of literacy overall. (Mary-Portas and Contrepois 2005; see also Kestermann 2005). A large proportion of female prisoners were not in employment or were working in precarious and/or low skilled jobs prior to their incarceration and even though most had children, relatively few were living with a partner (Mary-Portas and Contrepois 2005). As in a more recent English study (Gray, Simmonds and Annison 2016), the earlier comparative study found that high proportions of imprisoned women had suffered physical and/or sexual abuse as a child or from their partner. There were also high levels of drug use and mental health problems identified among women prior to their imprisonment (Mary-Portas and Contrepois 2005).

Women's routes into offending, the types of offences they commit and their reasons for offending are often different to those of men (Jamieson, McIvor and Murray 1999). This has clear implications for women's resettlement because the gendered nature of women's pathways to imprisonment means that their needs on release from prison are also likely to be different to those of men (Gelsthorpe and Sharpe 2007). Even where similar factors appear to have an association with offending by both women and men, how these needs originate, how they are manifested and how they interact with offending are likely to be highly gendered (Hollin and Palmer 2006; Gelsthorpe and Sharpe 2007; McIvor 2007). It has been argued that offending by girls and young women is more likely than that by young men to be linked to experiences of abuse, victimisation and health-related issues (including selfharm, depression, substance misuse and attempted suicide). In addition, social expectations of femininity may place pressure on girls and young women to live up to these expectations (Bateman and Hazel 2014).

Studies of women's routes into crime (and imprisonment) have sought to develop typologies to better understand and theorise women's involvement in lawbreaking. Although there has been less consensus regarding the number and nature of relevant typologies, drug use among women has been consistently identified as an important gendered pathway into crime (e.g. Daly 1998; Leverentz 2006; Salisbury and van Voorhis 2009; Opsal 2011). Women's offending may also be related indirectly to experiences of victimisation through, for example, the misuse of drugs as a form of self-medication to address the trauma associated with underlying experiences of abuse (Scroggins and Malley 2010).

Women's offending is also often linked to economic and social marginalisation, with crimes frequently committed under the influence of male partners. For example, Cruells, Igareda and Torrens (2005) identified a frequent connection between drug use and violence in the European jurisdictions that they studied. They found that young women could be compelled 
to commit a crime by a man who is violent towards them and become increasingly marginalised as a result both of experiencing abuse and escaping it. Despite this, women's experiences of victimization and violence were not being addressed either in prison or via post release policies and support (Cruells, Igareda and Torrens 2005).

\section{Offences and sentences}

The majority of criminal offending - especially involving more serious violent and sexual offending - is committed by men and women typically make up a relatively small proportion of prison populations internationally. For instance, Mary-Portas and Contrepois (2005) found that across the 6 jurisdictions that formed the basis of their European study, women made up between $4.0 \%$ (France) and $8.0 \%$ (Spain) of the prison population (including remands). Although women currently make up a slightly smaller proportion of prisoners in these jurisdictions (3.5\% in France and 7.5\% in Spain, for example) (Walmsley 2017), over the past two decades the numbers of women imprisoned in some European and other western jurisdictions has grown significantly, resulting in a steady growth in female prison populations and an increase in the percentage of female prisoners (Frost, Greene and Pranis 2007; Quaker Council for European Affairs 2007; McIvor 2010; Walmsley 2017).

Comparative research suggests that there are some variations in the types of offences for which women are imprisoned across European states, although in most jurisdictions poverty and drug related offending predominate (Mary-Portas and Contrepois 2005). While the ages of female prisoners vary, most are relatively young - under 40 years of age - with women from marginalized ethnic communities such as Roma women greatly over-represented in prison (Mary-Portas and Contrepois 2005; Pozo Gordalliza 2013). The proportion of foreign national prisoners varies across jurisdictions but tends to reflect differences in the numbers of women incarcerated for drug offences, with there being a tendency for foreign national prisoners to come from former colonies (Mary-Portas and Contrepois 2005).

Sentence lengths also differ across jurisdictions: in some most women are serving long sentences (>4-5 years) while in others (such as Germany) relatively few are (Mary-Portas and Contrepois 2005). In most jurisdictions, however, women are sentenced mostly for relatively minor offences and are often serving short sentences of less than one year including, in some jurisdictions, very short custodial sentences as a consequence of fine default. For example, Kerr (2014) found that $60 \%$ of female prisoners in Northern Ireland were serving sentences of less than one year, with just over half $(52 \%)$ of those received into custody in 2010 having been sentenced for fine default. In many jurisdictions a sizable proportion of women in prison are being held on remand prior to conviction or sentence. In Northern Ireland, for instance, 36\% of the female prison population in 2011 was being held on remand (Kerr 2014) while Mary-Portas and Contrepois (2005) report that the female remand population ranged from $21 \%$ (in England and Wales) to $48 \%$ (in France).

Because of the short sentences they receive - or as a result of periods spend on remand imprisoned women's needs are unlikely to receive the attention they deserve. Short custodial sentences make it difficult to access appropriate prison based programmes and to plan and put into place post release services (Gelsthorpe and Sharpe 2007). In some jurisdictions early release arrangements will ensure that women have access to statutory supervision in the community following release while in others - such as Scotland - the majority of women will only be eligible for assistance and support on release from prison on 
a voluntary basis on account of their short sentence lengths (see McIvor, Graham and McNeill in this volume). Baldry (2011) points out that the post release needs of prisoners serving short prison sentences are not the same as those who have served longer sentences the former are more likely to have mental health problems and to be convicted and sentenced repeatedly for minor offences. She argues that a series of short sentences - which represents the most common experience of criminalized women - 'is a form of serial institutionalisation that is even more disruptive to positive engagement with the community and maintains more chaotic living than a longer sentence' (Baldry 2011: 256). Thus while there is evidence from Europe that recidivism rates, however defined, are lower among female than male prisoners (Mary-Portas and Contrepois 2005), there is also other evidence that in the absence of support, women may be more at risk of return to prison following a custodial sentence than similarly sentenced men (Baldry et al. 2003).

\section{The collateral consequences of imprisonment}

In order to better understand the resettlement needs of imprisoned women it is necessary to consider not only their experiences and circumstances prior to imprisonment but to take account, in addition, of the impact of imprisonment on women's relationships, resources and wellbeing. As we shall see, the experience of imprisonment can serve to further increase the vulnerability and marginalization of an already socially excluded and disadvantaged group.

There is a tension between having prisons that are sufficiently large in order that an appropriate range of relevant services can be provided to meet imprisoned women's needs and having women imprisoned closer to home but in small units that may lack appropriate supports and services and/or be attached to male institutions. As Gelsthorpe and Sharpe (2007: 208) observe, while men and women may share some overlap in needs 'criminal justice provision designed for men does not necessarily meet the needs of women'.

Moreover, as experience in some jurisdictions has shown, women held in female units attached to male institutions may find themselves having to share facilities with male prisoners - rendering them liable to sexual harassment - or having their movements within the institution excessively regulated and constrained (Scraton and Moore 2007; Kerr 2014).

\section{Relationships}

Studies across jurisdictions consistently indicate that women in prison are likely to be the mothers of dependent children and their primary caregivers. While estimates vary, studies typically suggest this to be the case in respect of around two-thirds of imprisoned women (e.g. Caddle and Crisp 1997; Hamlyn and Lewis 2000; Liebling and Maruna 2005; Dünkel 2005: Kestermann 2005; Fawcett Society 2006) and although the number of children affected by maternal imprisonment in any single jurisdiction is often difficult to ascertain, it has been estimated that around 17,000 children in England and Wales are affected by maternal imprisonment in any year (Fawcett Society 2006). Men in prison are less likely to be fathers and those who are less likely to have been directly responsible for the care of their children prior to their imprisonment (Beichner and Hagemann 2016). Imprisoned mothers are more likely than imprisoned fathers to have been living as lone parents prior to their incarceration and this has implications for the care of dependent children while they are serving their sentence (Minson et al. 2015). A UK study found that only 5 per cent of children remained in their own home when their mother was imprisoned and while they 
were most likely to be cared for by grandparents or other relatives, around one in eight were received into the care of public authorities (Caddle and Crisp 1997).

Maintaining contact with their children can present significant challenges for women. Women may forego visits from their children to shield them from the knowledge that they are serving a prison sentence (Gray, Simmonds and Annison 2016). Often women are accommodated in prisons far from home which creates difficulties for family visits as a consequence of travel time and costs and visiting facilities and home leaves are often inadequate (Cruells, Igareda and Torrens 2005; Nagy and Vig in this volume ). The quality and intensiveness of prison based parenting programmes and family support varies from classroom based courses to more intensive programmes that offer additional facilities such as special visiting areas for mothers and children (Beichner and Hagemann 2016)

Most countries allow some women to have their children with them during their imprisonment, usually from birth to around 6 years (Robertson 2012; Barbaret 2014). Some countries - such as Spain - have made greater efforts to accommodate motherhood in prisons including allowing children to live with both parents if they are incarcerated. Denmark, Sweden and Finland also allow children to stay with both incarcerated fathers and mothers (Barbaret 2014). In the Family House of Engelsborg, Denmark, prisoners can live with their children and partner during the final period of incarceration, with support provided by a family therapist and social worker. Preliminary research suggests that the project has positive benefits for the families involved (Beichner and Hagemann 2016).

The negative effects on children of maternal incarceration have been well documented (Caddle and Crisp 1997; Hissel, Bijleveld and Kruttschnitt 2011; Beichner and Hagemann 2016). Children whose mothers are imprisoned may develop a range of problems such as emotional withdrawal, ill health and eating disorders and they may exhibit behavioural problems, though, as Hissel, Bijleveld and Kruttschnitt (2011) observe, it can be difficult to disentangle the effects of maternal imprisonment from other factors such as children's prior family experiences.

When children have been taken into care or their mother has received a lengthy sentence, reestablishing relationships between them can be particularly challenging (Pruin 2016). In the absence of financial and social support, some women may seek not to regain custody of their children at least until their living arrangements are more stable. Re-establishing relationships with children can be facilitated by opportunities for women to maintain relationships with them while in prison and to have regular visits with them after release (O’Brien 2001)

Codd (2007) urges a cautious approach to involving prisoners' families in the process of resettlement not least because it can let the state step back from providing necessary services and supports. However, supportive family networks appear to be invaluable for women both while they are in prison and on their release, with positive family relationships assisting women to rebuild their lives and avoid further offending when they return to the community (Maidment 2006; Bateman and Hazel 2014). Women in prison often do not, however, have such supportive networks as a result of histories of physical and sexual abuse or the breakdown in relationships following reception into prison or other institutions and relationships with partners are often 'a major source of turmoil and abuse in women's lives'(Maidment 2006: 117). Some women may tolerate abusive relationships to prevent 
themselves from becoming homeless and avoid poverty when they are released from prison (Wilkinson 2004; Cruells, Igareda and Torrens 2005; Gelsthorpe and Sharpe 2007). Even when their partners are supportive, women may find it difficult to adjust as a result of experiencing depression, learning to cope again and feeling overwhelmed by family and other problems (Wilkinson 2004).

\section{Accommodation}

Prior to offending, women's accommodation is typically precarious (Cruells, Igareda and Torrens 2005) and serving a prison sentence can create further accommodation problems (Reid Howie Associates 2016). Obtaining safe and affordable housing is an immediate concern for many women on release, especially since securing access to state benefits usually requires a fixed address and regaining custody of their children will be dependent upon securing suitable accommodation. Often, however, women are uncertain where they will live when they leave prison (Niven and Stewart 2004; Roberson and Radford 2006) and many experience housing problems following their release (Wilkinson 2004; Zurhold et al. 2011). Although male prisoners may also face challenges securing appropriate accommodation on release, women are more at risk of losing their accommodation while in prison because they are less likely to have a partner who can maintain their tenancy while they are serving a prison sentence (Morris et al. 1995; Wilkinson 2004).

Studies in the UK have suggested that fewer than half of women leaving prison will return to the same address that they lived at prior to their incarceration (Hamlyn and Lewis 2000) and that around one third of women lose their accommodation (and possessions) while in prison (Niven and Stewart 2004). Women may lose their pre-prison accommodation as a result of relationship breakdown or because they have been unable to have their housing costs met while they are in prison (Cruells, Igareda and Torrens 2005). This may come about because entitlement to housing benefits is time limited or because housing problems have not been identified while the woman is in prison resulting in a build-up of arrears.

Obtaining safe and secure accommodation can be a significant challenge for women who are unable to return to their former homes (Pruin 2016) not least because of an absence of legal requirements in many European states to provide female ex-prisoners with housing (Cruells, Igareda and Torrens 2005). Being imprisoned far from their home area can make it difficult for women to liaise with potential housing providers prior to their release while loss of possessions while in custody and increased arrears can be a barrier to securing and maintaining housing on release (Reid Howie Associates 2016).

Women who leave prison without alternative arrangements may be offered post-release accommodation that does not allow mothers and their children to live together, that fails to recognise the difficulties of living with others (especially in the context of mixed sex accommodation), that does not recognise the impact of prior victimization on women and that is located far from women's family and social networks (Cruells, Igareda and Torrens 2005). In Scotland, for example, homeless women are likely to be accommodated in a hostel until their accommodation needs can be assessed and this can be a difficult environment especially if women are also recovering from abusive relationships, mental health problems or substance misuse (McCallum 2012). Housing problems are often interwoven with other complex issues yet supported accommodation is likely to be in short supply and, if available, may have restrictions such that women with histories of violence, drug misuse or 
mental health problems are denied access. In Scotland, the lack of adequate accommodation for women has been identified as rendering some highly vulnerable on release from custody (Malloch 2013; Commission on Women Offenders 2012).

Housing problems can, in turn, result in other problems that make successful resettlement less likely. For instance, Gray, Simmonds and Annison (2016) found that housing problems led in some cases to substance misuse and to concerns about women's capacity to be reunited with their children while an Australian study found that homelessness and lack of accommodation support were associated with an increased risk of being returned to prison as a result of further offending (Baldry et al. 2003). Women leaving prison may find themselves accommodated in poor quality housing in areas with high crime rates and high levels of drug and alcohol use that can have a detrimental effect on their reintegration, wellbeing and sense of safety (Maidment 2006; McIvor, Trotter and Sheehan 2009; Reid Howie Associates 2016). Living in certain types of temporary accommodation - such as hostels may also create problems, including the ready availability of drugs and alcohol and a lack of security. Housing insecurity can also impact upon women's ability to obtain employment and financial independence because of the difficulties associated with applying for a job without a permanent address, the difficulty in looking clean and tidy for interviews or work without the necessary facilities to do so and because concern about housing becomes a distraction that makes it difficult to engage in the search for work (Reid Howie Associates 2016).

\section{Employment, education and training}

Prior to their imprisonment, women are likely to have experienced financial hardship and to have been in receipt of state benefits or poorly paid employment (Hamlyn and Lewis 2000; Cruells, Igareda and Torrens 2005). Often women are confused over their entitlement to benefits (Gelsthorpe and Sharpe 2007) and their debts may worsen during the period of imprisonment (Wilkinson 2004). Female prisoners are amongst the most disadvantaged groups in terms of education level and employability. Lack of education and training can serve as a barrier to resettlement since it reduces the likelihood of finding employment. Women often report that lack of money is the main problem facing them when they leave prison because of the delays that occur before they receive state financial support. In some cases this may result in women borrowing money and acquiring debts that later need to be paid off or engaging further offending as a means of economic survival (Gelsthorpe and Sharpe 2007).

Despite the potential for employment to offer women a means of achieving financial independence, there is evidence that imprisoned women have more limited opportunities for meaningful prison based employment, education and training than do men. Only Sweden (Persson and Svensson in this volume) explicitly acknowledges the importance of increasing women's employability to enhance their post-release interrogation. As Pruin (2016) has observed, women tend to be imprisoned in relatively small facilities that are able to provide only limited training and educational opportunities and given the short sentences that women often serve, opportunities for skills acquisition are necessarily limited (Wilkinson 2004). In their comparative European study, Cruells, Igareda and Torrens (2005) found that women had less access to training activities and to existing prison jobs. While there may some instances of women located in units within mixed sex prisons having better access to 
educational, vocational and therapeutic opportunities, Cruells, Igareda and Torrens (2005) found that in these circumstances work opportunities for women tended to be segregated and to result in significant differences in earnings between male and female prisoners.

Employment and training women's prisons has also been criticised for failing to prepare women to meet external labour market demands by offering training and employment opportunities that develop skills and capacities that are associated with the traditional feminine role but which are not valued and are poorly paid in the labour market (Cruells, Igareda and Torrens, 2005; O'Keefe, Senior and Monti-Holland 2007; also Nagy and Vig in this volume). Women's work tends not to be tailored to individual need and is often perceived as routine, mindless and boring (O'Keefe, Senior and Monti-Holland 2007). It often involves assisting in the running and maintenance of the prison, with women unlikely to be offered a job that includes recognised vocational training (Hamlyn and Lewis 2000). It is therefore not surprising that several studies have found that women do not consider prison-based work as being likely to help them secure employment on their release (e.g. Hamlyn and Lewis 2000; O'Brien 2001), with post- release labour market success related to pre-prison work experience rather than employment, training and education in prison (Hamlyn and Lewis 2000).

In a US study O'Brien (2001) found that legitimately obtained financial stability was a key factor in enabling women to reintegrate successfully because 'having a means of legal income became a springboard for everything else that that women had to do in reestablishing themselves after prison' (O'Brien 2001: 118). However it has also been argued that as a result of their educational and employment backgrounds and their experiences of imprisonment, women leaving prison are even more vulnerable to unemployment, temporary employment and part-time employment (Cruells, Igareda and Torrens 2005) and any employment they do secure may not provide sufficient income on which to live (Wilkinson 2004).

The other barriers to employment that women face include having a criminal record and the stigma associated with their ex-prisoner status, financial problems or debt, access to appropriate childcare and access to education in the absence of suitable accommodation (Gray, Simmonds and Annison 2016). However, some studies have suggested that finding post-release employment may be a lower priority for women because other issues - such as finding accommodation, regaining custody of their children and avoiding a resumption of drug misuse - need to be addressed first (MacRae et al. 2006; Gelsthorpe and Sharpe 2007; O'Keefe, Senior and Monti-Holland 2007).

\section{Physical and mental health}

Compared with the wider population, women in prison tend to have higher levels of physical and mental health problems often associated with poverty and disadvantage (Kestermann 2005). For example, the proportion of female prisoners in European prisons with a drug problem has been estimated to be relatively high in many jurisdictions, ranging from 50-80\% of imprisoned women (Zurhold et al. 2011). Despite this, and despite known differences in women's drug use and its trajectory, prison based drug programmes tend to have been developed for men (Cruells, Igareda and Torrens 2005; Pruin 2016) and the quality of drug treatment programmes for female prisoners varies widely even though there is evidence that prison-based treatment and planning for release can facilitate reintegration 
and is 'essential for improving the women's confidence in community life' (Zurhold et al. 2011, p. 59).

International literature suggests that relapse among female drug users is often linked to inadequate preparation for release, deprived living conditions and a persistent drug problem after release (Baldry et al. 2003). However, a comparative European study of throughcare for drug using prisoners found that provision failed to differentiate between the needs of distinctive prisoner groups such as women and was at different stages of development in different jurisdictions (MacDonald, Williams and Cane 2012). Providing effective services to drug users both in prisons and following release requires that those with drug problems are identified as such, though this does not necessarily occur (MacDonald, Williams and Cane 2012). The rapid turnover of prisoners makes prison based drug assessments a challenge and also makes it difficult for community-based drugs workers to develop relationships with women prior to their release (Fox et al. 2005; MacRae et al. 2006). Moreover, the fear of being labelled as an irresponsible mother - and losing care of their children - may deter women from seeking drug treatment (Cruells, Igareda and Torrens 2005)

Substance misuse among female prisoners is often linked to other issues such as trauma and mental health problems with alcohol and drugs used as a form of self-medication to deal with personal distress. High levels of mental health problems have been identified among female prisoners (Kestermann 2005), with this being a particular concern in Sweden (Persson and Svensson in this volume). Roberson and Radford (2006) found that a high proportion of imprisoned women in Northern Ireland had physical and mental health issues and three-quarters had experienced significant bereavement in the previous 5 years while around one half of female prisoners in Scotland's only dedicated female prison were accessing mental health services in prison (Mackie and Thorpe 2014). The incidence of mental health problems among released female drug users in Zurhold et al.'s (2011) study varied from $60-70 \%$ and enduring mental health problems meant that women who otherwise had a good chance of successful resettlement were still in need of ongoing support following release. In some jurisdictions - such as Spain - over medication of women in prison can make reintegration more difficult by encouraging dependency on prescribed drugs (Cruells, Igareda and Torrens 2005).

There are relatively high levels of self-harm and suicide among female prisoners (e.g. Loucks 2004; Kestermann 2005; Coles 2013). It has been suggested that this may be related to women in prison suffering greater psychological distress as a result of separation from their children and through being exposed to practices such as strip searching, urine testing and intrusive observation and monitoring that can re-traumatise victims of sexual abuse (Cruells, Igareda and Torrens, 2005). Female prisoners are likely to have been victims of physical, sexual or emotional abuse as an adult and/or a child and need access to appropriate services (Green et al. 2005; Pruin 2016), though a recent study by Gray, Simmonds and Annison (2016) indicated that some women with had histories of sexual and physical abuse and some had not sought help with this in custody either because they did not recognise themselves as victims or thought that they were to blame. Women who had sought support either had not received it or did not necessarily find it to have been helpful (Gray, Simmonds and Annison 2016). By contrast, the limited research examining art therapy and 
educational theatre for imprisoned women appears to demonstrate encouraging results (Beichner and Hagemann 2016).

Female prisoners tend also to have serious physical health problems related to their backgrounds and lifestyles and reflecting a range of social inequalities though the distinctive health needs of women in prison tend not to be addressed appropriately (Cruells, Igareda and Torrens 2005). A recent review of prison health services in Scotland found evidence that many health needs were being missed under existing throughcare arrangements with the risk that any health gains achieved in prison could be lost when prisoners were released (Mackie and Thorpe 2014).

\section{Resettlement and desistance}

Female prisoners are a particularly vulnerable group with distinctive needs as regards resettlement. Imprisonment may serve to further marginalise already socially excluded women who are likely to face significant difficulties reintegrating into society unless appropriate services are made available to address the unique issues that they face (Scroggins and Malley 2010; Malloch 2013) and to prevent high rates of post release death and harm that may arise from the instability of women's lives following release (Carlton and Baldry 2013).

Because women tend to have a multiplicity of problems resettlement services are likely to require and benefit from the involvement and co-ordination of a range of voluntary and statutory organisations to address issues such as childcare and parenting skills; healthcare, counselling and substance misuse services; housing and transport; education, employment and training; and social support (Cobbina 2010; Scroggins and Malley 2010). It is also important, in view of the complexity of women's needs, that services can be made available, if necessary, over an extended period of time (Gelsthorpe and Sharpe 2007).

Levels of recidivism tend to be relatively high among women released from prison who have received their sentences for property, drug and public order offences (Scroggins and Malley 2010) and the risk of re-offending appears to be particularly high in the period immediately following release (Pruin 2016). However, there is also some evidence that effective pre-release preparation and post-release support may reduce the risk of recidivism among formerly imprisoned women (Dowden and Andrews 1999). In particular, stability of living arrangements on release, along with family support, employment or education and having support from other agencies that is valued have been shown to be associated with successfully staying out of prison (Baldry 2003; McIvor, Trotter and Sheehan 2009).

Because there is an overlap between their resettlement needs and needs which place women at risk of further offending (Gelsthorpe and Sharpe 2007) important pointers may be drawn from the desistance literature regarding those services that might both promote women's resettlement and support them in their endeavours to lead law-abiding lives, while recognising that these processes are likely to be rooted within forms of wider structural disadvantage that may impact upon women's feelings of safety (Kerr 2014; Roberson and Radford 2006) and make further offending a practical means to ensure economic survival (Gelsthorpe and Sharpe 2007).

Desistance appears to be a process involving both structural and subjective changes (Maruna 2001; Gelsthorpe and Sharpe 2007; Rodermond et al. 2016). Not only must there be relevant 
'hooks for change' (Giordiano, Cernkovich and Rudolph 2002) but women need to be committed to achieving and sustaining desistance and believe that they have the capacity to do so (McIvor, Trotter and Sheehan 2009; Rodermond et al. 2016). The desistance literature suggests, for example, that family and social support networks are critical to successful reintegration and desistance among women (Dowden and Andrews 1999) since they enable women to 'establish a connection with law-abiding citizens and conventional institutions, while simultaneously providing them with a legitimate identity' (Cobbina 2010: 213).

In their review Rodermond et al. (2016) identified a number of other factors associated with female desistance. These included motherhood, supportive personal relationships, employment, education, improvements in mental health and drug use and achieving economic independence. Overall, relationships appear to be more important for women's desistance than for men's while employment is less relevant to understanding desistance among women, possibly because the jobs secured by women tend to be relatively menial and poorly paid (Rodermond et al. 2016).

However, the desistance literature also highlights the complexity of the process: for example, Rodermond et al. (2016) suggest that while motherhood often provides women with a motivation to avoid further offending, economic pressures associated with it may undermine efforts to desist. Similarly, having children has been found to be associated with desistance only if other factors - such as problematic drug use - have been addressed (McIvor 2016). In this regard, the desistance literature supports the conclusions from studies of female resettlement that a co-ordinated package of services is likely to be required. Thus, consistent with Gray, Simmonds and Annison's (2016) finding that female prisoners who were less confident about their ability to desist 'were those who were facing release without stable accommodation, with little idea about financial stability and were facing the prospect of mixing with their old social networks and isolation from family' (p. vii), Rodermond et al. (2016: 22) conclude that 'in order to promote desistance, it is critical to provide recently convicted females with a range of assistance related to housing, financial support, relationships, employment and drug use' along with supportive services aimed at enabling women to acquire both the motivation and personal agency to desist (see also McIvor, Trotter and Sheehan 2009; Durnescu 2011).

\section{Approaches to effective resettlement}

While the preceding discussion has focused upon the types of support that women are likely to require when they return from prison to the community, we now turn to the mechanisms or procedures which have been identified as likely to be associated with effective resettlement. It should be noted that reviews which have sought to identify elements of effective throughcare practice have tended to focus on male prisoners or not to specify the gender of the prisoners concerned. However, some of the general principles which emerge are likely to be equally applicable to men and to women (Dowden and Andrews 1999).

As O'Brien (2001) has argued although the process of transition 'may begin with the motivational strength of the woman herself, it is generated within an environment that actively promotes or discourages the process by virtue of the resources she can access along the way' (O'Brien 2001: 126). The importance of a co-ordinated approach in which the resettlement process begins in prison and continues into the community is increasingly acknowledged (Pruin 2016). Prisons and external service providers should aim to provide a 
comprehensive and holistic service that is gender responsive, with interventions provided in an environment in which women feel safe (Bateman and Hazel 2014). It has been argued that early contact should be made with prisoners in order that needs can be identified and pre-release planning can begin, with an emphasis on linking prisoners to external services and service providers to facilitate continuity of service provision before and after release.

Prison based programmes and pre-release services should aim to address prisoners' immediate needs while developing human capital that will facilitate the transition to the community and social capital that will support women's reintegration on release (Durnescu 2011; Malloch et al. 2012). A case management approach may assist in co-ordinating input from different services (Durnescu 2011) or a dedicated liaison worker can help to ensure that joint working between different agencies both inside and outside the prison remains a priority (Malloch et al. 2012). Contact at the gate or shortly thereafter appears to be very important in supporting the prisoner as they move into the community, ensuring early engagement with services (Malloch et al. 2012) while other practical measures such as half way houses or other forms of temporary housing can facilitate the transition and provide a base from which women can seek to secure more stable accommodation and work (Durnescu 2011; Malloch et al. 2012).

Malloch et al. (2012) conclude from their international review that prisoners should be actively involved in developing support plans and in identifying programmes aimed at meeting their needs and highlight the importance of consistency in staffing to enable trusting relationships to develop. They also argue that some flexibility in working practices is necessary to enable pre and post release service providers to respond to issues as they occur and recognise that the transition process will require different priorities at different points in time. Effective partnership working involves shared priorities between agencies and a willingness to work together and services need to be sufficiently resourced.

A number of studies have pointed to the important role played by supervisors and service providers in the resettlement process, reflecting the central importance of supportive relationships for women. How they relate to women appears to be critical, with successful reintegration having been found to be associated with criminal justice personnel who treated women with respect and believed in their potential to change (O'Brien 2001; Maidment 2006), and who demonstrated a willingness to listen, encourage and provide emotional and practical support (Cobbina 2010; Trotter, McIvor and Shaahan 2012).

As Pruin (2016) notes, a number of international frameworks exist to encourage the development of effective resettlement practice with women, including the 2011 UN Rules for the Treatment of Women Prisoners and Noncustodial Measures for Women Offenders (the Bangkok Rules) which stress the importance of visits to maintain family ties and of graduated release mechanisms and which identify the need for prisons and other organisations to develop and deliver services prior to and following release which have regard to the specific needs of women (see also Krabbe and van Kempen 2017). Further recommendations for gender appropriate release preparation are articulated in UNODOC 2008 which highlights the need for a co-ordinated approach across agencies and between prison and the community, a focus on the provision of practical assistance and psychological support and an emphasis on supporting and strengthening family relationships (Pruin 2016). 
Many of the contributions to this volume do not refer to specific resettlement approaches for women. This may indicate that gender specific provision is not yet widely developed in Europe nor are women generally recognised as having distinctive resettlement needs. In some jurisdictions - such as France, Greece, Lithuania and Romania (see the relevant chapters in this volume) there is acknowledged to be no programmes that have been developed specifically for women while in others - such as Hungary (Nagy and Vig in this volume) - service development is described as sporadic and ad hoc. However there are examples internationally of gender specific resettlement programmes in the USA and in the UK (Beichner and Hagemann 2016) while the Netherlands has a half-way house specifically for women and their children (Boone and uit Beijerse in this volume) and, as previously indicated, several European countries have arrangements whereby women can live with their children (and partners) towards the end of their prison sentences to ease the transition back into the community (Barbaret 2014; also Anagnostaki in this volume).

In some jurisdictions there has been a more focused effort to provide resettlement services that meet the needs of imprisoned women. In Germany, for example, significantly increased use has been made of open prison conditions for women to facilitate their transition into the community following the recommendations by Dünkel (2005) based on an international study of women's imprisonment in Europe. In Scotland a number of initiatives have been introduced including the establishment in 2010 of community integration units for women at HMP Aberdeen and Inverness enabling a small number of low security female prisoners to be accommodated closer to home (Rome 2012) and the Circle Families Affected by Imprisonment (FABI) project which was established by a third sector provider in 2008 as a pilot throughcare service for women with children returning to certain geographical areas of Scotland, with a particular emphasis on women on remand and those serving short sentences who otherwise had little or no access to support. Around four-fifths of the women who had been released from custody during the first three years of the project had received no further custodial sentences and 'positive engagement' was reported to have been achieved with $85 \%$ of women following their release from custody. Women reported that they had valued emotional and practical support during the transition from custody to community to access and utilise relevant services (Hutton and Nugent 2011).

Mentoring has also been introduced in some jurisdictions - such as the USA (Villanueva 2008) and Australia (Brown and Ross 2010; 2011) - as a mechanism for supporting female prisoners on their return to the community. The effectiveness of mentoring support has yet to be established, though there is some evidence that women with relatively chaotic lifestyles may find it more difficult to engage (Brown and Ross 2010). Mentoring services for women have been introduced in Scotland through the Routes Out of Prison and Shine projects with encouraging results (see McIvor, Graham and McNeill in this volume). It has been suggested that mentoring should be taken forward in the context of a strengths based approach, assisting individuals to define their goals and to access the personal and practical resources that are necessary to achieve them (Hucklesby and Wincup 2014).

\section{Women's experiences of resettlement}

Although there are some encouraging developments in the resettlement of female prisoners, there is evidence that women's experiences are often characterised by poor preparation in prison prior to release and poor support in the community thereafter. Post-release provision 
varies widely between and within jurisdictions but is generally limited (Beichner and Hagemann 2016). The resettlement needs of women and girls tend to be overlooked partly because they represent a small proportion of prisoners and partly because they tend to offend less often and seriously than men and boys (Bateman and Hazel 2014). Even in a country like Scotland which has comparatively well-developed provision, geographical disparity in service provision has been identified, with some women offered multiple sources of assistance while others are offered little or none (Commission on Women Offenders 2012; Malloch 2013).

Several UK studies have found that most women believed that they had not been given sufficient help while in prison or encouraged to plan for their release (Morris et al 1995; Hamlyn and Lewis 2000; Roberson and Radford 2006; Gray, Simmonds and Annison 2016). Elsewhere, Pruin (2016) cites the study by Tóth (2005) of women's imprisonment in 5 European countries which found that pre-release preparation was poorly implemented. Although women who had made contact with organisations that could provide support prior to their release through graduated release were reported to have had an easier transition back into the community, Zolondek (2007, cited in Pruin 2016) found that prison leaves were rarely granted in the context of pre-release preparation and many women in Tóth's (2005) study reported receiving no support on release. As a consequence:

'...the burden of having to find accommodation, secure an income and reestablish family ties, all simultaneously, appeared to be too much for many of the women to carry. Finding employment while bearing the "ex-prisoner" stigma proved virtually impossible, and many women had thus been quickly confronted with an unstable and difficult economic situation.'(Pruin 2016: 164).

The experiences of women in these studies are by no means unique. For instance Morris et al. (1995) found that women's post-release experiences were characterised by housing instability, financial insecurity, relationship breakdown and unemployment while Hamlyn and Lewis (2000) reported that the majority of women leaving prison experienced problems following their release. Women in Cobbina's (2010) study often linked their lack of success in resettlement to the competing demands that they faced - such as having to find a job while fulfilling other parole requirements and caring for their children - with resultant feelings of anxiety and stress exacerbated when women did not have reliable social support. Some of the women interviewed by O'Brien (2001) found the expectations placed on them following their release from prison intrusive and overwhelming.

Post-release services for women leaving prison tend to be fragmented, poorly co-ordinated and not necessarily related to their needs (Scroggins and Malley 2010). Short term funding can cause problems if projects do not have sufficient time to set up effective partnerships before financial support runs out (Malloch et al. 2012). A contemporary policy focus in some jurisdictions on outcome targets may render gender specific services unattractive to funders because there is limited evidence of their effectiveness and the small numbers involved may make it difficult for service providers to demonstrate that outcomes have been achieved (Bateman and Hazel 2014). Accessing mainstream services may also prove problematic for women leaving prison because of their lack of self-confidence and selfesteem and the judgmental attitudes of professionals who are not accustomed to dealing with this particularly stigmatised group (McCallum 2012). 


\section{Conclusions}

As Scroggins and Malley (2010: 147) have observed, 'patterns of marginalization that women experience throughout their lives create unique problems that must be addressed if successful re-entry is to be achieved'. As this chapter has shown, however, criminalized women have a complex range of problems and needs that are often not addressed in prison or following their release. Moreover, the difficulties that women face on release are compounded by gendered inequalities in society meaning that incarcerated women 'face a number of unique challenges in the journey home from prison' (Beichner and Hagemann 2016: 93).

In many western jurisdictions there has been heightened policy attention to resettlement that has resulted in the expansion of surveillance by the state at the same time as austerity measures have resulted in cuts in public spending. Particularly in neo-liberal states, increasing numbers of prisoners are being made subject to post release supervision and scrutiny by criminal justice agencies and there is evidence of increasing involvement of non-statutory organisations in performing the controlling role of the state (Shaylor and Meinders 2013). This is well exemplified, for example, in England and Wales (Padfield in this volume) which has recently experienced an expansion of formal post release supervision with evidence of a significant expansion of 'back door' imprisonment through the breach of post release licence or supervision requirements and increased involvement of the private and third sector in this process.

It has been suggested that the primary concern of post-prison supervision has become programme compliance and that the programmes that are in place are transitory, inadequate and leave most women's needs unmet (Bumiller 2013). It has been argued that resettlement policies are failing women and in so doing are contributing to rather than reducing 'the criminalisation and imprisonment of socially disadvantaged and marginalised women' (Kerr 2014: 12). In the context of diminishing social welfare provision, prison arguably 'becomes a possible stopgap against the inadequacy of social services, available housing, and lack of jobs' (Bumiller 2013: 24).

Effective resettlement service for women involve partnership working between relevant criminal justice and other agencies such as housing, employment, health and social security because the problems that underlie offending are rooted in wider forms of economic and social disadvantage (Malloch 2013). Thus while the criminal justice system may have a legislated responsibility to support and/or supervise offenders on their release from prison, the concern is essentially about securing access to social justice. As Gelsthorpe and Sharpe (2007: 218, original emphasis) have similarly argued, '[u]ltimately, the task of resettlement is one of connecting women to agency support networks beyond the criminal justice system'. Rather than being determined by what services exist, resettlement policies and practice need to be informed by women's experiences and needs and underpinned by wider strategies aimed at eradicating gendered forms of social disadvantage. 


\section{References}

Baldry, E. (2011):'Women in transition: From prison to...', Current Issues in Criminal Justice, 22 (2), 253-67.

Baldry, E., et al. (2003): Ex-prisoners and Accommodation: What bearing do Different Forms of Housing have on Social Reintegration?, Melbourne, Vic.: Australian Housing and Urban Research Institute.

Barbaret, R. (2014): Women, Crime and Criminal Justice: A Global Enquiry, London: Routledge.

Bateman, T. and Hazel, N. (2014): Beyond Youth Custody: Resettlement of Girls and Young Women, London: Nacro.

Beichner, D. and Hagemann, O. (2016): 'Incarcerated women: Their situation, their needs and measures for sustainable reintegration', in H. Kury, S. Redo and E. Shea (eds.) Women and Children as Victims and Offenders: Backgrounds, Prevention, Reintegration Suggestions for Succeeding Generations (Volume 2), Cham: Springer Publishing, pp. 85116.

Blanchette, K. and Brown, S.L. (2006): The Assessment and Treatment of Women Offenders, Chichester: Wiley.

Brown, M. and Ross, S. (2010): 'Mentoring, social capital and desistance: A study of women released from prison', Australian and New Zealand Journal of Criminology, 43 (1), 31-50.

Brown, M. and Ross, S. (2011): 'Assisting and supporting women released from prison: Is mentoring the answer?', Current Issues in Criminal Justice, 22 (2), 217-232.

Bumiller (2013): 'Incareration, welfare state and labour market nexus: The increasing significance of gender in the prison system', in B. Carlton and M. Segrave (eds.) Women Exiting Prison: Critical Essays on Gender, Post-release Support and Survival, London: Routledge, pp. 13-33.

Caddle, D. and Crisp, D. (1997): Imprisoned Women and Mothers, Home Office Research Study 162, London: Home Office.

Carlton, B. and Baldry, E. (2013): 'Therapeutic correctional spaces, transcarceral interventions: Post-release support structures and realities experienced by women in Victoria, Australia', in B. Carlton and M. Segrave (eds.) Women Exiting Prison: Critical Essays on Gender, Post-release Support and Survival, London: Routledge, pp. 56-76.

Cobbina, J.E. (2010): 'Reintegration success and failure: Factors impacting reintegration among incarcerated and formerly incarcerated women', Journal of Offender Rehabilitation, 49, 210-32.

Codd, H. (2007): 'Prisoners' families and resettlement: A critical analysis', The Howard Journal, 46 (3), 255-63. 
Coles, D. (2013): 'Deaths of women in prison: The human rights issues arising', in M. Malloch and G. McIvor (eds.) Women, Punishment and Social Justice: Human Rights and Penal Practices, London: Routledge, pp.39-51.

Commission on Women Offenders (2012): Report of the Commission on Women Offenders, Edinburgh: Commission on Women Offenders.

Cruells, M., Igareda, N. and Torrens, M. (2005): 'Including the gender perspective in the penal, penitentiary, and post-prison policies', in M. Cruells and N. Igareda (eds.) Women, Integration and Prison, Barcelona: Aurea Editores, pp. 68-81.

Daly, K. (1998): 'Women's pathways to felony court: Feminist theories of lawbreaking and problems of representation', in K. Daly and L. Maher (eds.) Criminology at the Crossroads: Feminist Readings in Crime and Justice, New York, NY: Oxford University Press, pp. 135154.

Dowden, C. and Andrews, D.A. (1999): 'What works with female offenders? - A metaanalytic approach', Crime and Delinquency, 45 (4), 438-452.

Dünkel, F. (2005): 'Outlook - 5 theses on women's imprisonment' in F Dünkel, C.

Kestermann and J. Zolondek (eds.) International Study on Women's Imprisonment. Current situation, demand analysis and "best practice". Internet-publication https://rsf.unigreifswald.de/lehrstuehle/ehemalige-lehrstuehle/strafrecht/lehrstuhlduenkel/forschungsprojekte/frauenstrafvollzug-2003-2005/, pp. 40-43.

Dünkel, F., Kestermann, C. and Zolondek, J. (2005) (eds.): International Study on Women's Imprisonment. Current situation, demand analysis and "best practice". Internet-publication https://rsf.uni-greifswald.de/lehrstuehle/ehemalige-lehrstuehle/strafrecht/lehrstuhlduenkel/forschungsprojekte/frauenstrafvollzug-2003-2005/.

Durnescu, I. (2011): Resettlement Research and Practices: An International Perspective, Utrecht: CEP.

Fawcett Society (2006): Justice and Equality: Second Annual Review of The Commission on Women and the Criminal Justice System, London: Fawcett Society.

Fox, A., et al. (2005): Throughcare and Aftercare: Approaches and Promising Practice in Service Delivery for Clients Released from Prison or Leaving Residential Rehabilitation, London: Home Office.

Frost, N.A., Greene, J. and Pranis, K. (2006): Hard Hit: The Growth in the Imprisonment of Women, 1977-2004, New York, NY: Institute on Women and Criminal Justice.

Gelsthorpe, L. and Sharpe, G. (2007): 'Women and resettlement', in A. Hucklesby and L/ Hagley-Dickinson (eds.) Prisoner Resettlement: Policy and Practice, Cullompton: Willan Publishing, pp.199-223 .

Giordano, P.C., Cernkovich, S.A. and Rudolph, J.L. (2002): 'Gender, crime and desistance: Toward a theory of cognitive transformation', American Journal of Sociology, 107 (4), 9901064. 
Gray, P., Simmonds, L. and Annison, J. (2016): The Resettlement of Women Offenders: Learning the Lessons, Plymouth: Plymouth University.

Green, B. L. (2005): 'Trauma exposure, mental health functioning, and program needs of women in jail', Crime and Delinquency, 51 (1), 133-151.

Hamlyn, B. and Lewis, D. (2000): Women Prisoners: A Survey of their Work and Training Experiences in Custody and on Release, Home Office Research Study 208, London: Home office.

Hissel, S., Bijleveld, C. and Kruttschnitt, C. (2011): 'The well-being of children of incarcerated mothers: An exploratory study for the Netherlands', European Journal of Criminology, 8(5), 346-360.

Hollin, C. and Palmer, E. (2006): 'Criminogenic need and women offenders: A critique of the literature', Legal and Criminological Psychology, 11 (2), 179-195.

Hucklesby, A. and Wincup, E. (2014) 'Assistance, support and monitoring? The paradoxes of mentoring adults in the criminal justice system', Journal of Social Policy, 43 (2): 373-90.

Hutton, L. and Nugent, B. (2011): Circle's Families Affected by Imprisonment Project: Throughcare for Female Offenders - A Report on Outcomes in Relation to the 3-year Service Evaluation, Glasgow: The Robertson Trust.

Jamieson, J., McIvor, G. and Murray, C. (1999): Understanding Offending Among Young People, Edinburgh: The Stationery Office.

Kerr, J. (2014): The Resettlement of Women prisoners in Northern Ireland: From Rhetoric to Reality, London: Howard league for Penal.

Kestermann, C. (2005): 'Training curriculum for women's prisons - health issues', in F Dünkel, C. Kestermann and J. Zolondek (eds.) International Study on Women's Imprisonment. Current situation, demand analysis and "best practice". Internet-publication https://rsf.uni-greifswald.de/lehrstuehle/ehemalige-lehrstuehle/strafrecht/lehrstuhlduenkel/forschungsprojekte/frauenstrafvollzug-2003-2005/ , pp 19-39.

Krabbe, M. and van Kempen, P.H. (2017): 'Women in prison: A transnational perspective', in P.H. van Kempen and M. Krabbe (eds.) Women in Prison: The Bangkok Rules and Beyond, Cambridge: Intersentia, pp. 3-34.

Liebling, A. and Maruna, S. (2005): The Effects of Imprisonment, Cullompton: Willan.

Leverentz, A.M. (2006): 'The love of a good man? Romantic relationships as a source of support or hinderance for female ex-offenders', Journal of Research in Crime and Delinquency, 43 (4), 459-488.

Loucks, N. (2004): 'Women in prison', in G. McIvor (ed.) Women who Offend: Research Highlights in Social Work 44, London: Jessica Kingsley, pp. 142-158.

MacDonald, M., Williams, J. and Kane, D. (2012): 'Barriers to implementing throughcare for problematic drug users in European prisons', International Journal of Prisoner Health, 8 (2), 68-84. 
Mackie, P. and Thorpe, A. (2014): Review of Health Care Needs of Prisoners in Relation to Throughcare, Glasgow: Scottish Public Health Network.

MacRae, R., et al. (2006): Evaluation of the Scottish Prison Service Transitional Care Initiative, Edinburgh: Scottish Executive Social Research.

Maidment, M.R. (2006): Doing Time on the Outside: Deconstructing the Benevolent Community, Toronto: University of Toronto Press.

Malloch, M. (2013): The Elements of Effective Throughcare Part 2: Scottish Review, Stirling: Scottish Centre for Crime and Justice Research.

Malloch, M., McIvor, G., Schinkel, M. and Armstrong, S. (2012): The Elements of Effective Throughcare Part 1: International Review, Stirling and Glasgow: Scottish Centre for Crime and Justice Research.

Maruna, S. (2001): Making Good: How Ex-Convicts Reform and Rebuild their Lives, Washington, DC: American Psychological Association.

Mary-Portas, F.L. and Contrepois, S. (2005): 'Recent trends: Incarcerated women in Europe', in M. Cruells and N. Igareda (eds.) Women, Integration and Prison, Barcelona: Aurea Editores, pp. 10-21.

McCallum, F. (2012): Justice Committee: Throughcare for Female Prisoners, Edinburgh: Scottish Parliament Information Centre.

McIvor, G. (2007): 'The nature of female offending', in R. Sheehan, G. McIvor and C. Trotter (eds.) What Works with Women Offenders, Cullompton: Willan Publishing, pp. 1-22.

McIvor, G. (2010): 'Women and crime: The rise in female imprisonment in western jurisdictions', in M. Herzog-Evans (ed.) Transnational Criminology Manual, Nijmegen: Wolf, pp. 553-570.

McIvor, G., Trotter, C. and Sheehan, R. (2009): 'Women, resettlement and desistance', Probation Journal, 56 (4), 347-361.

Minson, S., Nadin, R. and Earle, J. (2015): Sentencing of Mothers: Improving the Sentencing Process and Outcomes for Women with Dependent Children, London: Prison Reform Trust.

Morris, A., Wilkinson, C., Tisi, A., Woodrow, J. and Rockley, A. (1995): Managing the Needs of Female Prisoners, London: Home Office.

Niven, S. and Stewart, D. (2004): Resettlement Outcomes on Release from Prison in 2003, London: Home Office.

O'Brien, P. (2001): Making it in the 'Free World': Women in Transition from Prison, Albany, NY: State University of New York Press.

O’Keefe, C., Senior, P. and Monti-Holland, V. (2007): 'Barriers to employment, training and education in prison and beyond': A peer-led solution', in R. Sheehan, G. McIvor and C. Trotter (eds.) What Works with Women Offenders, Cullompton: Willan, pp. 240-261. 
Opsal, T. (2012): 'Livin' on the straights': Identity, desistance, and work among women post-incarceration', Sociological Inquiry, 82 (3), 378-403.

Pozo Gordaliza, R. (2013): 'Tracking the invisible: Young Gitana women and punishment in Andalucia', in M. Malloch and G. McIvor (eds.) Women, Punishment and Social Justice: Human Rights and Penal Practices, London: Routledge, pp. 178-193.

Pruin, I. (2016): 'Release management for female and juvenile prisoners: How important is release management in prison for crime prevention?' in H. Kury, S. Redo and E. Shea (eds.) Women and Children as Victims and Offenders: Backgrounds, Prevention, Reintegration Suggestions for Succeeding Generations (Volume 2), Cham: Springer Publishing, pp. 145171.

Quaker Council for European Affairs (2007): Women in Prison: A Review of the Conditions in Member States of the Council of Europe, Brussels: QCEA.

Reid Howie Associates (2016): Housing and Reoffending: Supporting People who Serve Short-term Sentences to Secure and Sustain Stable Accommodation on Liberation, Edinburgh: Scottish Government Social Research.

Roberson, B. and Radford, E. (2006); 'The reintegration needs of women prisoners in Northern Ireland', Irish probation Journal, 3 (1), 110-115.

Robertson, O. (2012): Collateral Convicts: Children of Incarcerated Parents, Geneva: The Quaker United Nations Office.

Rodermond, E., et al. (2016); 'Female desistance: A review of the literature', European Journal of Criminology, 13 (1), 3-28.

Rome, A. (2012): Evaluation of the Female Community Integration Units in HMP Aberdeen and HMP Inverness, Edinburgh: Scottish Prison Service.

Salisbury, E.J. and Van Voorhis, P. (2009): 'Gendered pathways: A quantitative investigation of women probationers' paths to incarceration', Criminal Justice and Behavior, 36 (6), 541-566.

Scraton, P. and Moore, L. (2007): The Prison Within: The Imprisonment of Women in Northern Ireland, Belfast: NIHRC.

Scroggins, J.R. and Malley, S. (2010): 'Reentry and the (unmet) needs of women', Journal of Offender Rehabilitation, 49, 146-163.

Shaylor, C. and Meiners, E. (2013): 'Resisting gendered carceral lanscapes', in B. Carlton and M. Segrave (eds.) Women Exiting Prison: Critical Essays on Gender, Post-release Support and Survival, London: Routledge, pp. 181-199.

Tóth, H. (2005): Women, Integration and Prison: An Analysis of the Processes of SocioLabor Integration of Women after Prison in Europe - Comparative Report based on National Reports' Fieldwork Findings, Budapest: Center for Policy Studies.

Trotter, C., McIvor, G. and Sheehan, R. (2012): 'The effectiveness of support and rehabilitation services for women offenders', Australian Social Work, 65 (1), 6-20. 
Villanueva, C. (2008): Mentoring Women in Reentry: A WPA Practice Brief, New York, NY: Women's Prison Association.

Walmsley, R. (2017): World Female Imprisonment List - Fourth Edition, London: Institute for Criminal Policy Research.

Wilkinson, C. (2004): 'Women's release from prison: The case for change', in G. McIvor (ed.) Women Who Offend, London: Jessica Kingsley, pp. 159-182.

Zolondek, J. (2007): Lebens- und Haftbedingungen im Deutschen und Europäischen Frauenstrafvollzug, Mönchengladbach: Forum Verlag Godesberg.

Zurhold, H., et al. (2011): 'What affects reintegration of female drug users after prison release? Results of a European follow-up study', Journal of Offender Rehabilitation, 50, 49-65. 